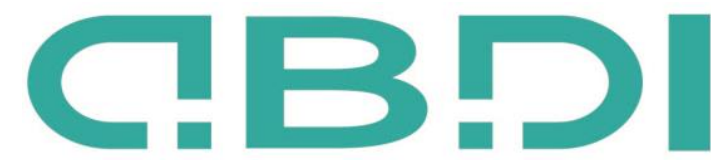

ABDI: JURNAL PENGABDIAN DAN PEMBERDAYAAN MASYARAKAT

\title{
Penguatan Kompetensi Guru Biologi Sidoarjo Menghasilkan Buku Ajar Bebas Plagiarisme
}

\author{
Iman Pasu Marganda Hadiarto Purba ${ }^{1}$, Hebert Adrianto ${ }^{2}$, Hanna Tabita Hasianna Silitonga ${ }^{3}$ \\ ${ }^{1}$ Universitas Negeri Surabaya \\ ${ }^{2,3}$ Universitas Ciputra Surabaya
}

E-mail: imanpurba@unesa.ac.id, hebert.rubay@ciputra.ac.id, hanna.silitonga@ciputra.ac.id

\begin{abstract}
Abstrak
Pembuatan buku ajar merupakan salah satu strategi penting didalam meningkatkan produktivitas dan efektivitas proses belajar mengajar di sekolah. Buku ajar tidak saja merupakan salah satu media pembelajar yang sifatnya suplemen lagi. Buku ajar menjadi kebutuhan dan media pembelajaran efektif meningkatkan kualitas pembelajaran bagi siswa. Namun, pembuatan buku ajar tidak terlepas dari tantangan terjadinya plagiarisme yang dapat berkonsekuensi hukum bagi penulis buku ajar, dalam hal ini guru. Di era digital saat ini kemudahan akses informasi menjadi tantangan besar bagi para guru penulis buku ajar karena karya yang dihasilkan cepat selesai namun melanggar etika penulisan karya. Oleh karenanya, khusus untuk guru yang bergabung di Musyawarah Guru Mata Pelajaran (MGMP) Sidoarjo, diberikan penguatan kompetensi guru menghasilkan buku ajar yang bebas plagiarisme. Metode pelaksanaanya melalui pelatihan yakni memberikan pembobotan aspek hukum plagiarisme dan pendampingan dengan metode Dalam Jaringan (Daring). Metode penilaian dilakukan dengan pre test dan post test, serta melakukan penguatan materi plagiarisme. Semua peserta merasakan manfaat yang sangat luar biasa sesuai dengan testimoni mereka karena selama ini mereka sering sekali mengabaikan aturan tentang plagiarisme. Guru Biolog ini akan menghasilkan buku ajar Biologi yang bebas dari plagiarisme dengan pemahanan dan keahlian baru para guru melakukan sitasi atau kutipan.
\end{abstract}

Kata kunci: Buku Ajar, Kompetensi, Plagiarisme, Penguatan

\section{Abstract}

Making textbooks is an important strategy in increasing the productivity and effectiveness of the teaching and learning process in schools. Textbooks are not only a supplementary learning medium. Textbooks are a necessity and effective learning media to improve the quality of learning for students. However, making textbooks is inseparable from the challenges of plagiarism which can have legal consequences for textbook authors, in this case teachers. In the current digital era, easy access to information is a big challenge for teachers who write textbooks because the work that is produced is quickly finished but violates the ethics of writing the work. Therefore, specifically for teachers who join the Sidoarjo Subject Teacher Conference (MGMP), teachers are given strengthening competencies to produce textbooks that are free of plagiarism. The method of implementation is through training, namely by providing weighting on the legal aspects of plagiarism and mentoring using the online method. The method of assessment is carried out by pre-test and post-test, as well as strengthening the plagiarism material. All the participants felt tremendous benefits according to their testimonials because so far they have often ignored the rules regarding plagiarism. This Biology teacher will produce a Biology textbook that is free from plagiarism with new insights and skills from the teachers in doing citations or quotations.

Key Word: Competence, Plagiarism, Strengthening, Textbook

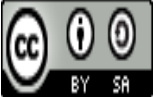

Received: 23 Oktober $2020 \quad$ Revised: 19 November $2020 \quad$ Available Online: 20 November 2020 


\section{Pendahuluan}

Penghormatan terhadap karya yang dihasilkan oleh manusia dalam bentuk apapun adalah merupakan bagian dari menjaga martabat dan kehormatan manusia itu sendiri. Karya menjadi salah satu bagian terpenting dari hidup manusia sebagai bagian dari eksistensinya ditengah-tengah komunitas maupun lingkungannya. Konteks keilmuan, baik Mahasiswa, Guru, Dosen maupun peneliti, karya yang dihasilkan akan mempengaruhi reputasi dan kualitas keilmuannya. Karya tulis merupakan karya yang mendominasi konteks keilmuan tersebut. Karya tersebut dapat berupa artikel, jurnal, modul, prosiding, dan buku. Menjaga nama baik dan reputasi terhadap karya yang dihasilkan menjadi bagian yang penting yang tidak dapat diabaikan sebagai bagian dari menjaga adab dan kehormatan atas keilmuan yang dimiliki.

Salah satu yang menjadi tantangan untuk menjaga reputasi dan orisinalitas dari karya yang dihasilkan adalah memastikan karya bukan merupakan hasil plagiarisme. Di era digital saat ini, tindakan plagiasi menjadi sesuatu yang sangat mudah dilakukan. Kemudahan mengakses data maupun informasi menjadi peluang yang sangat besar untuk menghasilkan karya yang instant, asal jadi, yang tentu itu merupakan tindakan menghina atau tidak menghormati keilmuan pelaku terlebih penghasil karya yang diplagiasi. Memberikan penghormatan dan penghargaan atas karya orang lain merupakan prinsip yang harus dipegang teguh didalam menghasilkan karya tulis.

Harus diakui tidak ada satupun karya tulis sepenuhnya original ataupun asli. Ilmu pengetahuan berkembang sesuai perkembagan zaman. Ada dinamika yang tidak dapat dipungkiri mempengaruhi keberadaan ilmu pengetahuan tersebut. Sehingga ketika hendak menuliskan sebuah karya tulis, kujujuran penulis didalam melakukan sitasi dan menyebutkan sumber rujukan yang dipakai didalam menuliskan karya tulis tersebut. Kejujuran didalam melakukan sitasi dan menyebutkan rujukan tersebut merupakan bagian dari menjaga martabat dan reputasi dari penulis itu sendiri. Kejujuran intelektual didalam melakukan sitasi dan menyebutkan rujukan tidak merendahkan bobot dan kualitas karya yang dihasilkan. Malah sebaliknya, karya tersebut semakin diakui validasi dan kualitasnya. Dibagian karya yang hasilkan akan terlihat mana saja yang merupakan gagasan dan hasil pemikiran orang lain manapula gagasan dan hasil pemikiran penulis tersebut.

Ada beberapa asumsi alasan penulis karya tulis menjadi Plagiator. Pertama, penulis karya tulis tersebut sama sekali tidak memiliki pemahaman yang baik tentang plagiasi. Bisa jadi menurut penulis hal itu merupakan hal yang tidak perlu dipermasalahkan. Kedua, penulis sengaja melakukan tindakan plagiasi karena memang tidak mampu menghasilkan karya tulis yang baik. Maka menghasilkan karya yang instan, mudah dan dapat dipublikasikan hanya dapat dilakukan dengan plagiasi. Ketiga, melakukan plagiasi memang sudah menjadi karakter penulis tersebut. Kejujuran intelektual yang harusnya dijunjung tinggi sama sekali tidak internalisasi didalam jiwa penulis tersebut. Keempat, penulis tidak mengetahui jika plagiarisme memiliki sanski hukum.

Di Indonesia, salah satu kasus plagiasi yang merdampak langsung tidak hanya kepada reputasi pelaku maupun oknum-oknum yang terlibat adalah kasus plagiasi yang terjadi di Universitas Negeri Jakarta.(Siti, 2017) Kasus plagiasi tersebut berimplikasi terhadap pemberhentian Rektor universitas tersebut. Kesungguhan lembaga pendidikan tinggi yang pada tahun itu masih bernaung di Kementerian Riset dan Pendidikan Tinggi (Kemenristek-Dikti) melalui Tim Evaluasi Kinerja Akdemik (EKA) menemukan bukti kuat terkait kasus plagiarisme di kampus tersebut. Hal membuktikan betapa plagiarisme adalah tindakan yang memalukan yang tidak hanya merusak reputasi dan kualifikasi keilmuan seseorang, namun merusak reputasi dan kualifikasi sebuah lembaga.

Program Kemitraan Masyarakat Stimulus (PKMS) yang berjudul "PKMS MGMP GURU BIOLOGI SMA DI SIDOARJO" memiliki tujuan untuk melanjutkan kerjasama menyelesaikan permasalahan yang belum masuk program PKMS pendanaan tahun 2019 lalu, dikarenakan penyesuaian dana dan waktu serta kekhususan kelas yang ditangani. Tahun sebelumnya materi biologi kelas 11 yang menjadi fokus masalah yang diselesaikan. Hasil wawancara didapatkan MGMP masih sangat membutuhkan tambahan pelatihan dari tim dosen Universitas Ciputra dan dosen Universitas Negeri Surabaya. Salah satu permasalahan yang ditemukan dari hasil observasi dan wawancara adalah terbatasnya kemampuan guru menghasilkan luaran ilmiah untuk kenaikan pangkat, khususnya buku. Oleh karena itu, salah satu hal yang perlu diperlengkapi kepada setiap guru adalah dengan memberikan 
pelatihan dan pendampingan bagaimana menghasilkan karya yang bebas dari plagiarisme. Sehingga karya ilmiah yang dihasilkan para guru dapat dipertanggungjawabkan sebagai karya yang memenuhi etika pembuatan karya ilmiha dan bebas dari plagiasi yang saat ini banyak sekali terjadi yang mempermalukan pribadi dari penulis karya maupun lembaga penghasil karya.

\section{Metode Pelaksanaan}

Konteks Guru Biologi yang bergabung di MGMP Sidoarjo, dari 5 orang guru perwakilan yang direkomendasi memiliki pemahaman yang tergolong rendah tentang aspek hukum plagiarisme. Kendatipun sudah banyak karya dihasilkan, para guru menyadari perihal aspek hukum demikian juga dengan cara melakukan citasi atau kutipan yang bebas plagiarisme masih kategori terbatas. Oleh karenanya dengan melakukan pelatihan secara Daring guna melakukan penguatan kompetensi menghasilkan buku ajar yang bebas plagiarisme memberikan manfaat besar bagi para guru ini. Kelima orang guru terpilih kemudian akan menjadi fasilitator bagi guru-guru lainnya untuk melatih dan membimbing rekan-rekan sejawat mereka di MGMP Biologi Sidoarjo. Dengan memberikan pre test dan post test, diketahui bagaimana pemahaman para guru tentang plagiarisme dan bagaimana pemahaman mereka sesudah mengikuti pembimbingan. Kemampuan melakukan citasi yang sesuai dengan etika penulisan dan bebas dari konsekuensi hukum plagiarisme juga sudah tercapai.

Pretest yang diberikan kepada 5 Guru yang menjadi Fasilitator di MGMP Biologi Sidoarjo diawali dengan pertanyaan dasar perihal plagiarisme. Mulai dari apa arti plagiat, plagiarisme, tipe plagiarisme, lalu dilanjutkan hal yang lebih mendalam tetang jenis plagiarisme dan cara melakukan plagiarisme. Lalu dilajutkan ke hal-hal yang lebih rumit namun sangat diperlukan ketika menghasilkan karya bebas plagiarisme yakni tentang hak kekayaan intelektual, peraturan tentang plagiarisme di Indonesia, Undang Undang tentang Hak Cipta, melakukan cek plagiasi dengan aplikasi yang sudah ada serta mendaftarkan karya tersebut kelembaga yang menerbitkan hak cipta yakni Depatertemen Hukum dan HAM, Direktrorat Jenderal Hak dan Kekayaan Intelektual.

Setelah melakuan pre-test dilanjutkan dengan pemberian materi dan penguatan materi serta pendalamannya seperti yang tampak pada gambar-gambar dibawah ini. Gambar 1 adalah gambar persiapan Pre Test yang dilakukan secara online dengan menggunakan pertanyaan pilihan berganda tentang plagiarisme. Dihadiri oleh 3 anggota tim Abdi Masyarakat.

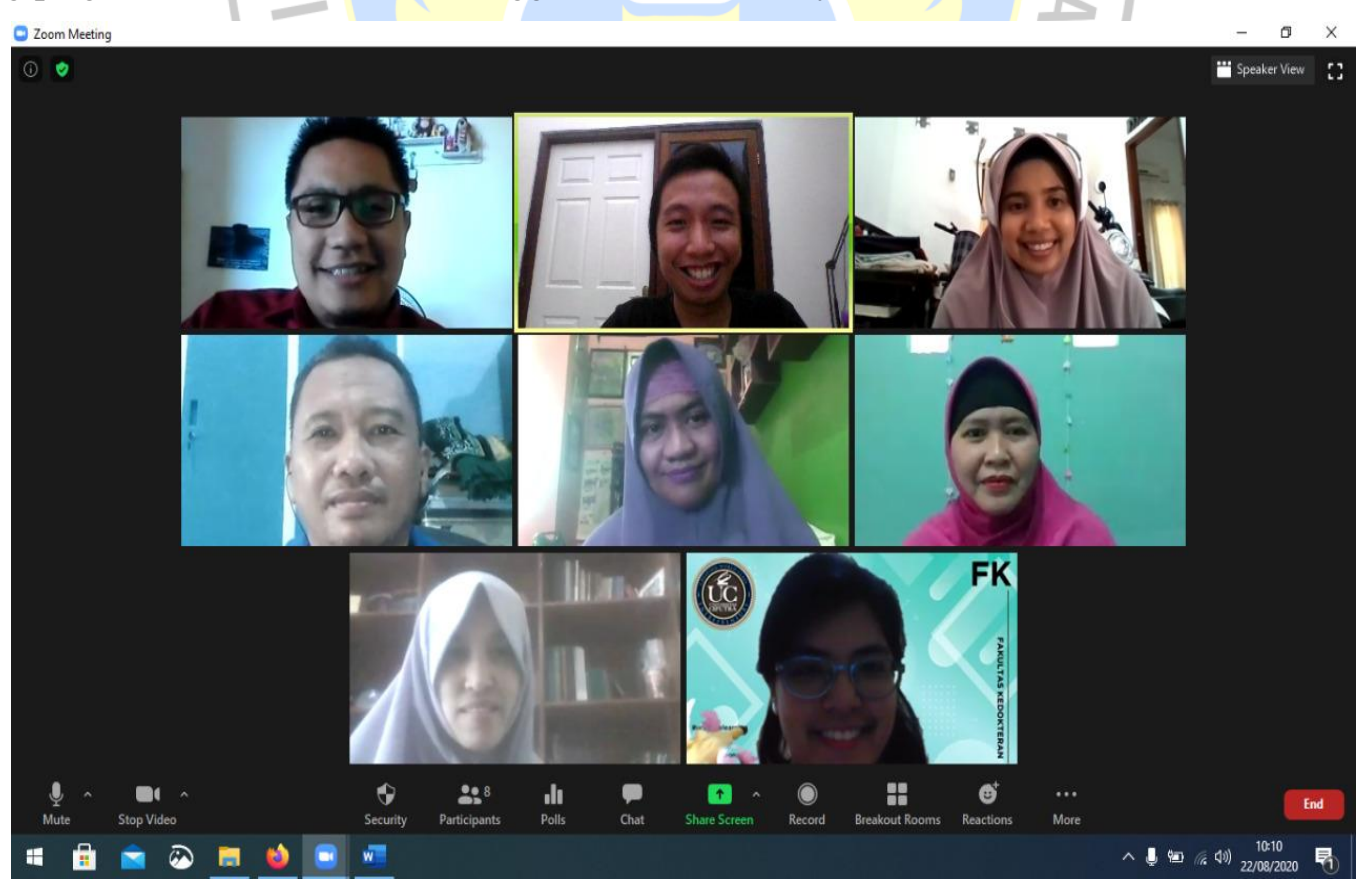

Gambar 1. Persiapan Pre Test

Lalu setelah Pretest dilakukan, maka penguatan materi dan pendalaman materi tentang plagiarisme yang menggambarkan semua pertanyaan-pertanyaan pada pre-test dilakukan. Mulai dari 
hal mendasar perihal plagiarisme sampai mendaftarkan karya cipta. Seperti terlihat pada Gambar 2 dan Gambar 3 dibawah ini.

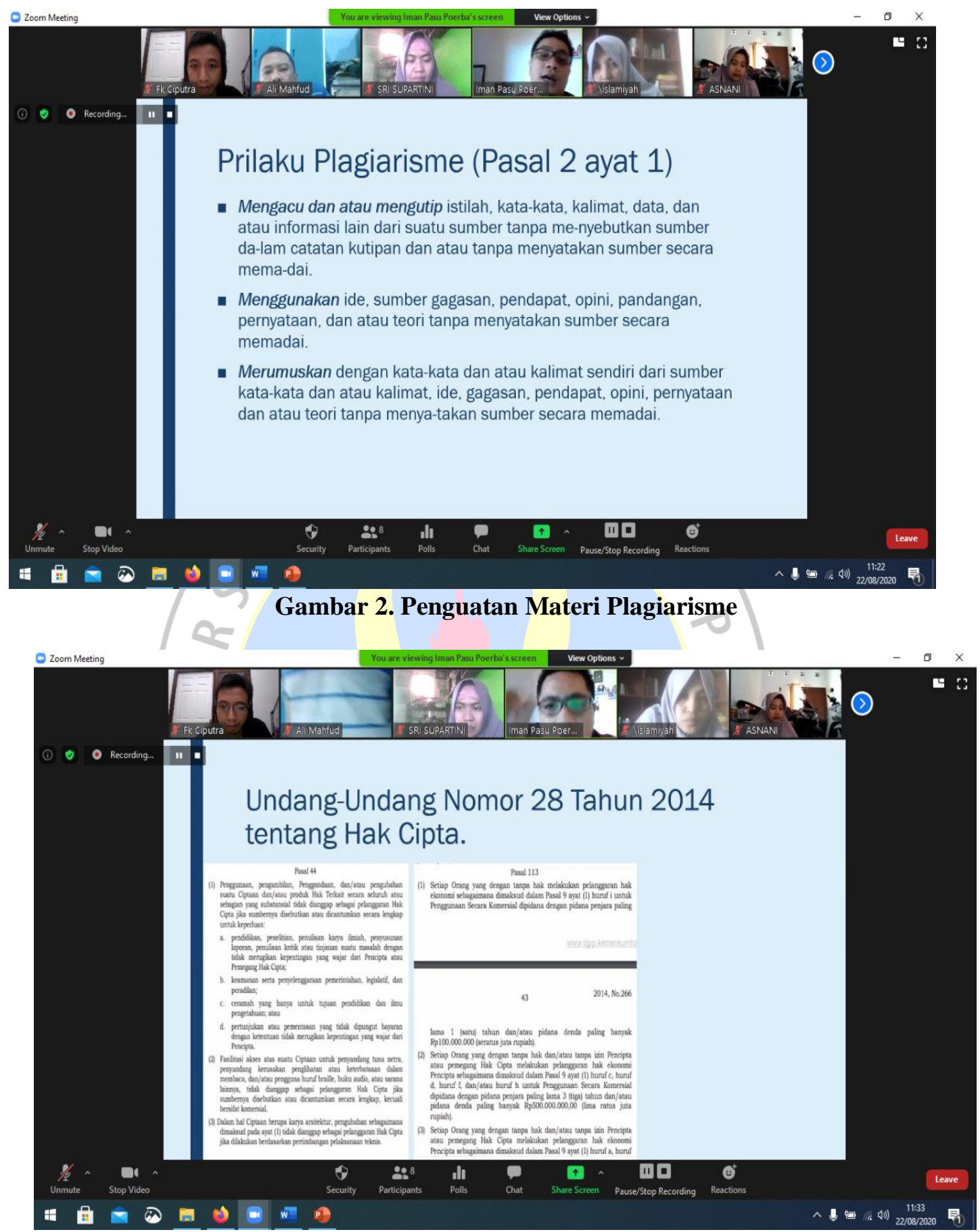

Gambar 3. Penguatan Materi Hak Cipta dan Pendaftaran HaKi

Setelah dilakukan penguatan materi dan pendalaman materi, maka dilanjutkan dengan menggali materi dengan memberi kesempatan tanya dan jawab kepada kelima peserta. Lalu langsung melakukan praktik cara melakukan citasi dan praktik melakukan parafrase. Hal yang harus dilatih beberapa kali adalah praktik melakukan parafrase. Para peserta dilatih untuk mampu memprafrase tulisan yang akan mereka citasi didalam karya ilmiah mereka. Selama ini hal yang sering mereka lakukan adalah melakukan kutipan langsung. Tentu cara inipun tidak menjadi masalah asalkan tetap melakukan atau 
mencatatkan sumber kutipan tersebut. Masing-masing peserta diminta membawa buku ilmiah lalu diminta menunjukkan bagian yang akan mereka citasi lalu diparafrase dan menuliskannya didalam daftar pustaka. Setelah melakukan kegiatan ini dan dipastikan semua sudah mampu dan berhasil melakukannya maka dilakukan kembali Post-Test untuk mengukur pemahaman semua peserta atas materi yang sudah disampaikan. Hasilnya juga sangat siginifikan menunjukkan bahwa kelima peserta berhasil mendapat hasil yang sangat memuaskan.

\section{Hasil dan Pembahasan}

Plagiat, Plagiasi dan Plagiarisme adalah kata yang sering dipakai untuk menunjukkan bahwa suatu karya baik tulis, maupun karya dalam bentuk lain merupakan karya yang tidak orisinil. Orisinil yang dimaksudkan tidak berarti jika karya tersebut benar-benar murni tanpa pendapat atau kutipan dari karya lain. Namun, pendapat dan kutipan terebut tidak dicantumkan sebagai sumber didalam menghasilkan sebuah karya yang terpublikasi kepada publik.

Kamus Besar Bahasa Indonesia (KBBI) plagiat adalah pengambilan karangan (pendapat dan sebagainya) orang lain dengan menjadikan seolah-olah karangan (pendapat dan sebagainya) sendiri. Misalnya menerbitkan karya tulis orang lain atas nama dirinya sendiri; jiplakan. (KBBI, 2020) Menurut KBBI ini secara sederhana dapat dipahami bahwa plagiat megambil karya orang lain dan mengklaim karya tersebut sebagai karya diri sendiri.

Kata Plagiasi sendiri tidak ada ditemukan didalam KBBI. Namun, kata ini juga sangat sering dipakai didalam kehidupan sehari-hari khususnya dalam kegiatan akademik. Namun, penggunaan kata "si" ini dapat dipahami menunjuk kepada "proses". Proses dapat dimaknai sebagai serangkaian tindakan atau peristiwa, pembuatan dan pengolahan untuk menghasilkan sesuatu. Sesuatu yang dihasilkan disini berupa karya. Baik karya tulis maupun karya dalam bentuk lain yang terpublikasi. Oleh karenanya, Plagiasi dapat dipahami sebagai serangkaian tindakan, pembuatan atau pengolahan suatu karya yang didalamnya ada unsur penjiplakan atau pengambilan karya orang lain dan menjadikannya seolah-olah merupakan karya sendiri.

Sementara itu arti kata Plagiarisme dapat ditemukan pada KBBI. Plagiarisme adalah penjiplakan yang melanggar hak cipta. (KBBI, 2020). Jika mengacu kepada arti plagiarisme tersebut dapat dipahami bahwa plagarisme merupakan suatu tindakan yang melawan hukum. Tindakan melawan hukum berarti memiliki konsekuensi hukum jika melakukan tindakan tersebut. Hal ini menyadarkan kaum intelektual bahwa setiap karya mereka haruslah didaftarkan ke Negara dalam hal ini mendaftarkannya ke Kementerian Hukum dan Hak Asasi Manusia, Direktorat Jenderal Kekayaan Intelektual.

Pendefenisian ketiga istilah tersebut diatas diharapkan mempermudah mengkategorisasi sebuah karya terindikasi hasil plagiat atau tidak. Karena tidak dapat dipungkiri bahwa tidaklah mudah untuk mengatakan suatu karya itu mengangdung plagiat atau tidak. Apakah karya tersebut merupakan hasil plagiasi yang berunjung pada simpulan bahwa plagiarisme terjadi atau tidak didalam menghasilkan suatu karya tersebut. Jika terjadi plagiarisme maka hal tersebut merupakan tindakan yang melanggar hukum dan ada konsekuesi hukum yang harus dihadapi oleh pelaku.

Hukum positif di Indonesia mendefenisikan Plagiat dengan sangat jelas pada Peraturan Menteri Pendidikan Nasional Republik Indonesia Nomor 17 tahun 2010 tentang Pencegahan dan Penanggulangan Plagiat di Perguruan Tinggi. "Plagiat adalah perbuatan secara sengaja atau tidak sengaja dalam memperoleh atau mencoba memperoleh kredit atau nilai untuk suatu karya ilmiah, dengan mengutip sebagian atau seluruh karya ilmiah pihak lain yang diakui sebagai karya ilmiahnya, tanpa menyatakan sumber secara tepat dan memadai.

Konteks Peraturan ini, yang dimaksudkan plagiat tindakan sengaja maupun tidak sengaja menghasilkan karya ilmiah untuk keperluan kredit pegawai yang mengutip karya orang lain sebagian maupuin seluruhnya sebagai karya miliknya tanpa menyatakan sumber secara jelas dan tepat. Sementera itu pelakunya disebut sebagai Plagiator.

"Plagiator adalah orang perseorangan atau kelompok atau pelaku plagiat, masing-masing bertindak untuk diri sendiri, untuk kelompok atau untuk dan atas nama suatu badan."

Defenisi Plagiarisme didalam ketentuan umum Peraturan Menteri Pendidikan tersebut ternyata senada dengan pendapat Reitz dalam Purwani dan Purwoko yang dikutip dari Online Dictionary for Library and Information Science yang mendefenisikan bahwa plagiarisme adalah; "Copying or closely 
imitating the work of another writer, composer, etc. Without permission and with the intention of passing the result of as original work" (Purwani, 2016). Jadi, Plagiarisme dimaknai sebagai tindakan meniru dan menjiplak pekerjaan dari penulis atau pengarang lain tanpa ijin dan maksud mengklaim bahwa karya tersebut adalah karya orisinalitasnya. Dengan mencantumkan sumber dari kutipan yang diambil itu dianggap upaya "meminta" ijin dari pemilik karya sebelumnya. Sekaligus tindakan tersebut sebagai penghormatan dan menhargai penulis sebelumnya.

Pelaku Plagiat atau Plagiator menurut defenisi tersebut tidak hanya dilakukan perorangan saja. melainkan juga bisa dilakukan kelompok bahkan pelaku plagiat yang tentunya kesemua pelaku dapat diminta pertanggungjawababan atau karya yang diplagiasi.Perihal karya yang diplagiasi juga didefenisikan secara jelas didalam peraturan ini. "Karya adalah hasil karya akademik atau nonakademik oleh orang perseorangan, kelompok, atau badan di luar lingkungan perguruan tinggi, baik yang diterbitkan, dipresentasikan, maupun dibuat dalam bentuk tertulis".

Karya yang diplagiasi tidak hanya meliputi karya akademik saja melainkan karya non akademik. Dimana karya tersebut diterbitkan, dipresentasikan ataupun dibuat didalam bentuk tertulis. Karya diterbitkan ini dapat berupa artikel, jurnal, prosiding maupun buku. Hal ini tentunya diterbutkan dalam bentuk tertulis. Jika karya yang dipresentasikan maksudnya karya tersebut dipresentasikan dalam temu ilmiah baik berupa seminar nasional, seminar internasional atau mimbar ilmiah lainnya. Bahkan saat ini di era digital, karya tersebut dipresentasikan dipertemuan-pertemuan ilmiah Dalam Jaringan (Daring) atau online.

Sementara itu menurut Oxford American Dictionary, Plagiarisme didefenisikan dengan "to take and use another person's ideas or writing inventions as one's own". Hampir sama dengan pendefenisian didalam KBBI, Plagiarisme dimaknai sebagai mengambil dan menggunanakan ide atau karya tulis atau penemuan sebagai salah satu kepunyaannya/karya pribadi (Claubaugh, 2001). Tindakan mengklaim atau menyatakan suatu karya original pribadi tetapi merupakan hasil plagiasi adalah tindakan plagiarisme yang dapat dimintai pertanggungjawaban kepada pelaku.

Ada tiga tipe plagiariseme menurut Cooper dalam Abdan Shadiqi menurut dari motivasi melakukan oleh Plagiator. Tiga tipe yang dimaksudkan adalah tipe intentional (sengaja), unintentional (tidak sengaja) dan inadvertent (kelalaian) (Abdan, 2019). Namun apapun yang menjadi motif ketiganya semua tindakan tersebut tetap dianggap sebagai plagiarisme yang memiliki konsekuensi yang harus ditanggung.

1. Intentional plagiarism adalah tindakan plagiarisme dimana plagiator secara sengaja melakukannya. Marshal dan Rowhland menggunakan istilah deliberate plagiarism. Baik kata maupun ide yang ada disebuah karya penulis lain diklaim didalam tulisan orisinal penulis. Hal ini merupakan pelanggaran terhadap penghormatan terhadap suatu karya intelektual karena pelaku secara sadar melakukannya. Bahkan ketika penulis sudah pernah pembublikasikan karyanya lalu menerbitkan karya yang sama di media publikasi yang berbeda, masuk kategori tindakan plagiarisme yang disengaja ini. Self plagiarism dianggap upaya untuk menipu orang lain oleh Park dan kejahatan yang secara sadar dilakukan.

2. Unintentional plagiarisme. Jenis tindakan plagiarisme ini berbeda motif dengan yang pertama. Sama sekali bertolak belakang dari jenis tapi kualitas perbuatan sama. Plagiator tidak sengaja sama sekali melakukan plagiasi. Konteks tindakan ini plagiator menyadari jika ide, gagasan, kata, atau frasa tetapi melupakan sumbernya. Ketidaksengajaan ini juga dipengaruhi oleh pemahaman penulis tentang kualifikasi dan batasan suatu tindakan plagiarisme. Barnet dan Campbell menilai hal tersebut merupakan suatu hal yang tidak disengaja (Barnett, J. E, 2012). Dia juga menambahkan tindakan plagiarisme yang tidak disengaja ini terjadi karena penulis tidak memahami tentang aturan plagiarisme baik itu aturan dasar tentang merujuk materi akademik, mengutip atau mensitasi, menuliskan ide, hingga menyusun daftar pustaka. Penguatan identitas penulisan menjadi hal yang penting untuk mengatasi plagiarisme yang dilakukans secara tidak sengaja ini.

3. Inadvertent plagiarisme. Tipe plagiarisme yang satu ini tidak mudah untuk membendakannya dengan tipe plagiarisme yang dilakukan secara tidak sengaja/ unintetional plagiarisme. Jika membaca pendefenisian saja, jenis plagiarisme ini juga dapat diidentifikasi sebagai plagiarisme yang dilakukan secara tidak sengaja. Unsur penciri jenis plagiarisme ini adalah adanya unsur kelalaian atau kelengahan dari penulis dengan mengacuhkan sumber pemikiran atau tidak mencatatnya 
sebagai bagian dari citasi karya ilmiah yang dihasilkannya. Tentu jika ingin membedakannya dengan jelas, maka salah satu cara untuk memastikannya adalah melakukan investigasi langsung kepada pelaku/plagiator. Selain itu alat bantu untuk melakukan proses pengecekan plagiasi semisal turnitin adalah salah satu cara membuktikan apa sebuah karya sedang diplagiasi atau tidak.

Menurut Soelistyo dalam Purwani dan Purwoko menyatakan bahwa ada beberapa tipe plagiariame didalam praktiknya (Soelistyo, 2011)

1. Word for Word Plagiarism. Dalam hal ini plagiator melakukan penjiplakan kata demi kata dan menggunakan kata-kata penulis lain tanpa melakukan sitasi atau pencantuman sumber.

2. Plagiarisme of Source. Plagiator memakai atau mengunakan gagasan penulis lain dan tanpa penyebutan sumber sebagai pengakuan terhadap penulis tersebut.

3. Plagiarisme of Authorship. Plagiator mengklaim bahwa karya tulis orang lain adalah karyanya. Plagiator sebagai pengarang karya yang bukan karyanya sendiri.

4. Self plagiarisme. Dalam hal ini Plagiator melakukan auto plagiasi dimana karyanya dipublikasikan pada lebih dari satu redaksi publikasi. Kendatipun itu karya sendiri, namun orisinalitasnya tidak diakui lagi ketika dipublikasikan lebih dari satu kali di badan atau lembaga publikasi yang berbeda. Sejatinya, penulis dapat menambahkan atau memperbaharui karyanya dengan menjadikan karya sebelumnya sebagai bagian kecil didalam karya yang baru.

Jika ditinjau dari cara melakukan plagiarisme, ada 3 tipe plagiarisme, yakni patchwriting, inappropriate praraphasing, dan summaries. Ketiga jenis plagiarisme ini menekankan poin yang sama yaitu penulis menyalin, melakukan perubahan dan menyingkatkan atau menyimpulkan tulisan orang lain dengan menggunakan pengutipan dan parafrase secara baik tetapi tidak menyebutkan sumbernya.

1. Patchwriting. Roig dalam Purwani dan Purwoko menyatakan bahwa tindakan plagirisme tipe ini dilakukan dengan menyalin teks yang sudah ada sebelumnya tanpa menyebutkan sumbernya. Hal ini termasuk menggunakan sinonim dan memperpendek atau memperpanjang frase lalu diklaim sebagai karya sendiri tanpa menyebutkan sumber sebagai citasi karyanya. Memastikan validitas pembulikasi karya menjadi hal yang penting dalam bagian ini. Di era digital saat ini, peluang melakukan plagiarisme mengguinakan cara ini sangat besar. Tetapi sering sekali akhirnya sumber tidak valid karena dipublikasi oleh media yang tidak tervalidasi, terideks atau terakreditasi.

2. Inproriate praraphrasing. Perbedaan dengan patchwriting jenis plagiarisme ini menyebutkan sumber orisinalnya. Penulis hanya merubah sedikit isi dari tulisan yang dikutip tetapi tidak diberi tanda petik untuk mengindikasikannya sebagai kutipan langsung. Sebenarnya hal yang sangat lumrah sekali jika melakukan kutipan langsung maupun tidak didalam menuliskan sebuah karya ilmiah. Jika ada ide pokok dari penulis lain lalu dikembangkan dengan kalimat sendiri atau sering disebut melakukan parafrase dan mencamtumkan sumber orisinalnya itu adalah hal yang biasa dan tidak masuk bagian plagiarisme. Namun, penulis yang melakukan plagiarisme ini hanya menambahkan atau mengurangi beberapa kata, namun sumber tulisannya dicantumkan. Mengembangkan ide pokok penulis lain dengan menggunakan kalimat sendiri tetapi tetap mencantumkan sumbernya menjadi bagian penting didalam menulis suatu karya ilmiah. Karena sejatinya justru tulisan atau karya ilmiah yang ditulis tidak berdasarkan beberapa sumber justeru diragukan keilmiahannya.

3. Summaries. Tindakan plagiarisme ini dilakukan terhadap karya dimana ada suatu karya disingkat penyajiannya dengan cara sedemikian rupa tetapi tidak mencantumkan sumber dan citasi dengan baik dan benar. Seharusnya penilis harus mampu mengkomunikasikan atau menyajikan pendapat dari penulis orisinal dengan kalimat yang berbeda tanpa mengurangi maksud dari penulis orisinal tersebut. Apalagi jika penulis berasal dari bahasa ibu yang berbeda atau bahasa pengantar resmi yang berbeda karena berbeda wilayah atau negara. Sangat memungkinkan jika penulis dari bahasa yang berbeda dengan penulis orisinal, penulis sekedar menterjemahkan saja tanpa mencoba mengembangkan ide pokok dari penulis orisinal tersebut untuk disajikan kepada publik sehingga semakin mudah dipahami. Tentu saja harus memastikan bahwa proses penerjemahan yang dilakukan secara benar dan tepat. Jika tidak ide pokok atau gagasan awal dari penulis orisinal dapat menjadi kabut ketika dipaparkan kepada orang lain yang membaca sebuah karya. 
Setelah melakukan penguatan materi dan pendalaman materi dengan materi plagiarisme diatas, ditemukan bahwa hasil praktik dari peserta melakukan citasi sangat memuaskan hasil pemahamannya juga sangat memuaskan. Seperti yang terlihat pada Tabel 1 dan Grafik 1 dibawah ini.

Tabel 1. Jawaban Pre-test dan Post Test

\begin{tabular}{|c|c|c|c|c|c|}
\hline \multirow[t]{2}{*}{ No } & \multirow[t]{2}{*}{ Pertanyaan } & \multicolumn{2}{|c|}{ Pre-test } & \multicolumn{2}{|c|}{ Post-test } \\
\hline & & $\begin{array}{l}\text { Jumlah } \\
\text { benar }\end{array}$ & $\%$-tase & $\begin{array}{l}\text { Jumlah } \\
\text { benar }\end{array}$ & $\%$-tase \\
\hline 1 & Apakah arti plagiat? & 4 & 80 & 5 & 100 \\
\hline 2 & Apakah arti plagiarisme? & 3 & 60 & 5 & 100 \\
\hline 3 & $\begin{array}{l}\text { Manakah yang bukan merupakan tipe } \\
\text { plagiarisme? }\end{array}$ & 0 & 0 & 5 & 100 \\
\hline 4 & $\begin{array}{l}\text { Manakah yang bukan merupakan jenis } \\
\text { plagiarisme berdasarkan cara melakukan? }\end{array}$ & 0 & 0 & 5 & 100 \\
\hline 5 & $\begin{array}{l}\text { Manakah yang tidak merupakan bagian } \\
\text { dari Hak Kekayaan Intelektual? }\end{array}$ & & & 5 & 100 \\
\hline 6 & $\begin{array}{l}\text { Apakah peraturan yang secara khusus dan } \\
\text { rigid mengatur perihal pelarangan } \\
\text { tindakan plagiarisme diperguruan tinggi? }\end{array}$ & 4 & & 5 & 100 \\
\hline 7 & $\begin{array}{l}\text { Apakah UU yang secara khusus mengatur } \\
\text { tentang Hak CIpta? }\end{array}$ & 2 & 40 & 5 & 100 \\
\hline 8 & $\begin{array}{l}\text { Apakah yang harus dilakukan untuk } \\
\text { menghindari plagiarisme? }\end{array}$ & 2 & 40 & 4 & 80 \\
\hline 9 & $\begin{array}{l}\text { Apakah salah satu aplikasi yang dapat } \\
\text { melakukan cek plagiasi? }\end{array}$ & & & 5 & 100 \\
\hline 10 & $\begin{array}{l}\text { Ke Lembaga manakah hak cipta } \\
\text { didaftarkan? }\end{array}$ & 5 & & 5 & 100 \\
\hline
\end{tabular}

Jika melihat hasil Pre Test dan Post Test dari tabel ini, dapat disimpulkan jika secara kognitif pemahaman kelima Guru Biologi meningkat sangat signifikan terlihat dari jumlah jawaban yang benar atau jumlah guru yang benar menjawab semua pertanyaan yang diajukan. Bahkan, Sebelumnya ada beberapa pertanyaan yang semua peserta tidak benar menjawabnya. Pertanyaan mengenai tipe dan jenis plagiarisme. Demikian juga ketidaktahuan peserta tentang aplikasi cek plagiasi menunjukkan belum sadarnya peserta tentang urgensi melakukan cek plagiasi. Namun untuk pemahaman tentang hak kekayaan intelektual dan pendaftaran hak cipta semua peserta sudah memahami namun teknis mendaftarkannya sama sekali tidak mengetahuinya. Jika dilihat dari grafik dibawah ini, maka rata-rata nilai Pre Test yang adalah 5,2 meningkat drastis ke rata-rata 9.2. 


\section{RATA-RATA NILAI PRE-TEST DAN POST- TEST}

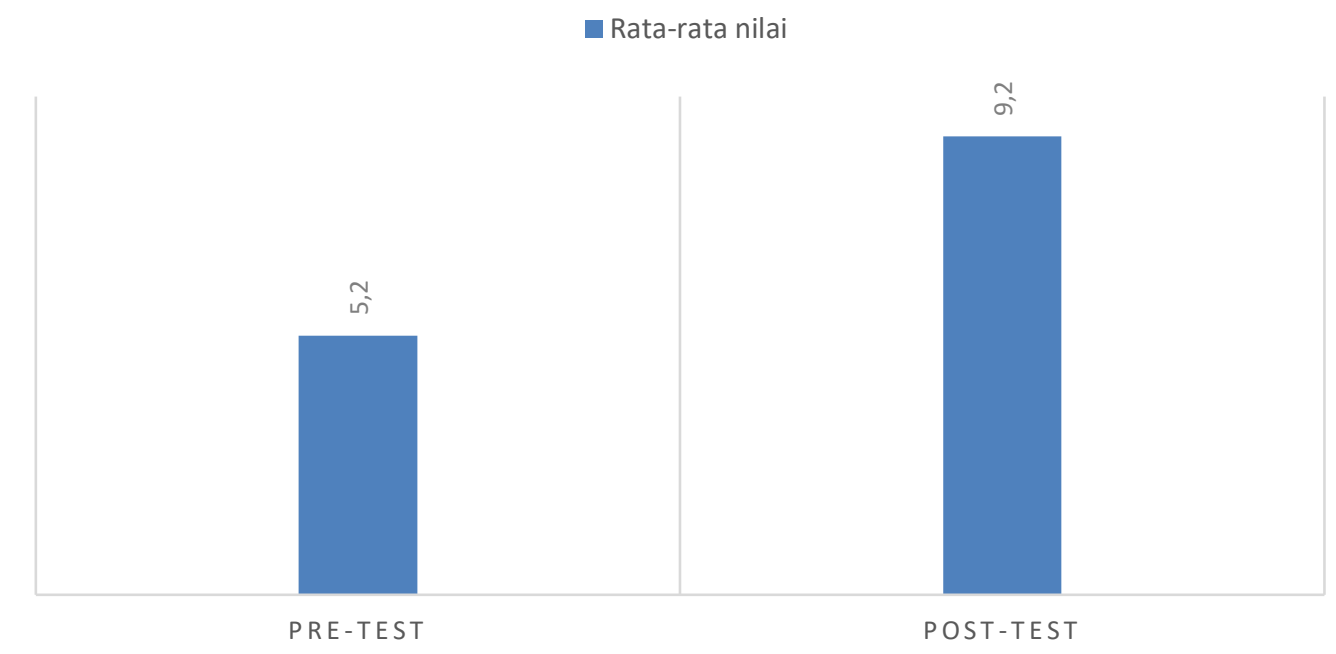

Gambar 4. Perubahan Nilai Rata-rata Pre-test dan Post-test

\section{Kesimpulan}

Hasil wawancara didapatkan MGMP masih sangat membutuhkan tambahan pelatihan dari tim dosen Universitas Ciputra dan dosen Universitas Negeri Surabaya. Salah satu permasalahan yang ditemukan dari hasil observasi dan wawancara adalah terbatasnya kemampuan guru menghasilkan luaran ilmiah untuk kenaikan pangkat, khususnya buku. Oleh karena itu, salah satu hal yang perlu diperlengkapi kepada setiap guru adalah dengan memberikan pelatihan dan pendampingan bagaimana menghasilkan karya yang bebas dari plagiarisme.

Konteks Guru Biologi yang bergabung di MGMP Sidoarjo, dari 5 orang guru perwakilan yang direkomendasi memiliki pemahaman yang tergolong rendah tentang aspek hukum plagiarisme. Kendatipun sudah banyak karya dihasilkan, para guru menyadari perihal aspek hukum demikian juga dengan cara melakukan citasi atau kutipan yang bebas plagiarisme masih kategori terbatas. Oleh karenanya dengan melakukan pelatihan secara Daring guna melakukan penguatan kompetensi menghasilkan buku ajar yang bebas plagiarisme memberikan manfaat besar bagi para guru ini. Kelima orang guru terpilih kemudian akan menjadi fasilitator bagi guru-guru lainnya untuk melatih dan membimbing rekan-rekan sejawat mereka di MGMP Biologi Sidoarjo. Dengan memberikan pre test dan post test, diketahui bagaimana pemahaman para guru tentang plagiarisme dan bagaimana pemahaman mereka sesudah mengikuti pembimbingan. Kemampuan melakukan citasi yang sesuai dengan etika penulisan dan bebas dari konsekuensi hukum plagiarisme juga sudah tercapai.

Jika melihat hasil Pre Test dan Post Test dari tabel ini, dapat disimpulkan jika secara kognitif pemahaman kelima Guru Biologi meningkat sangat signifikan terlihat dari jumlah jawaban yang benar atau jumlah guru yang benar menjawab semua pertanyaan yang diajukan. Jika dilihat dari grafik dibawah ini, maka rata-rata nilai Pre Test yang adalah 5,2 meningkat drastis ke rata-rata 9.2.

\section{Daftar Pustaka}

Abdan, S. (2019) Memahami dan Mencegah Perlilaju Plagiarisme dalam Menulis Karya Ilmiah, Yogyakarta: Buletin Psikologi UGM

Barnett, J. E., \& Campbell, L. F. (2012). Ethics issues in scholarship. In S. J. Knapp (Ed.), PA handbook of ethics in psychology: Vol. 2. Practice, teaching, and research. Washington, DC: American Psychological Association. 
Claubaugh, G.K. \& Rozycki, (2011) The Plagiarism Book: A Student's Manual. UK: EG

Kamus Besar Bahasa Indonesia (2020)

Peraturan Menteri Pendidikan Nasional Republik Indonesia Nomor 17 tahun 2010 tentang Pencegahan dan Penanggulangan Plagiat di Perguruan Tinggi.

Undang Undang Nomor 28 Tahun 2014 Tentang Hak Cipta

Siti, H. (2017, October). Pelaku Plagiarisme Harus Ditindak Tegas. Media Indonesia. Retrieved from https://Purwani \& Purwoko, Panduan Anti Plagiarisme, Yogyakarta: Perpustakaan UGM

Soelistyo. S. (2011) Plagiarisme: Pelanggaran Hak Cipta dan Etika. Yogyakarta: Penerbit Kanisius

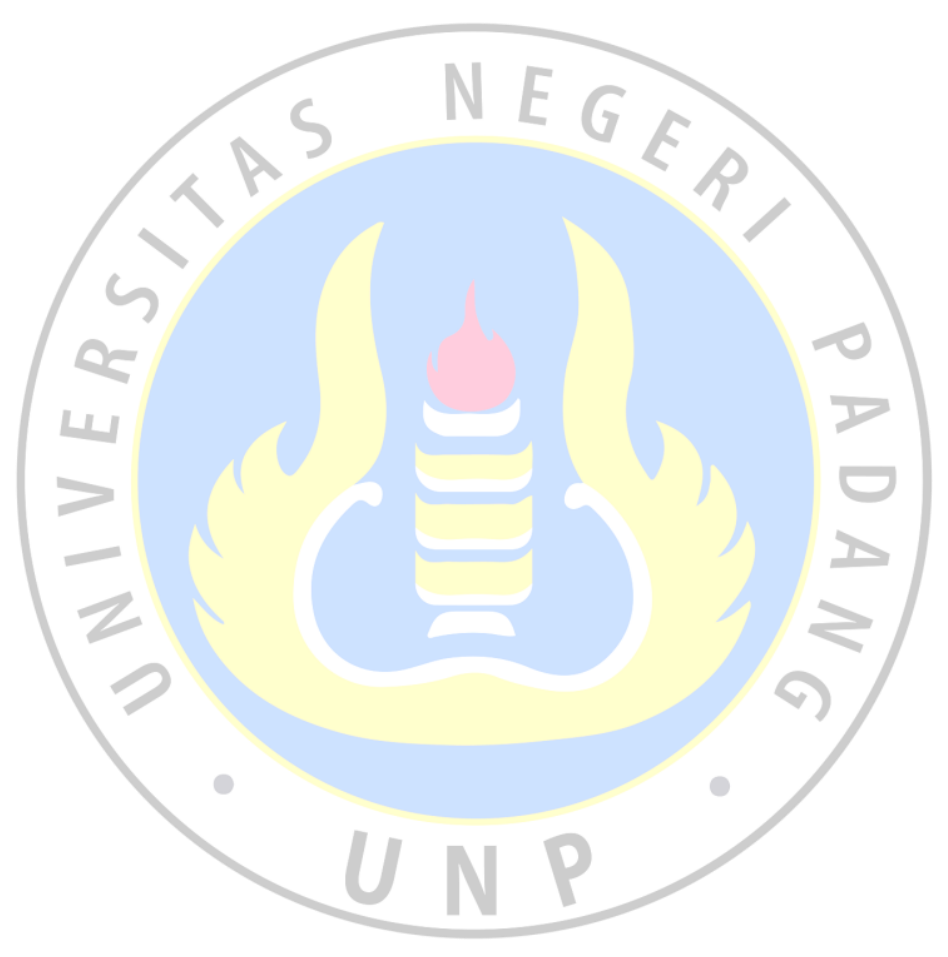

